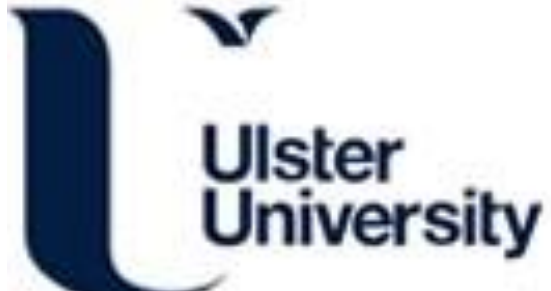

\section{Business intelligence systems and operational capability: an empirical analysis of high-tech sectors}

Yiu, L. M. D., Yeung, A., \& Jong, A. P. L. (2020). Business intelligence systems and operational capability: an empirical analysis of high-tech sectors. Industrial Management and Data Systems, 120(6), 1195-1215. https://doi.org/10.1108/IMDS-12-2019-0659

Link to publication record in Ulster University Research Portal

\section{Published in:}

Industrial Management and Data Systems

Publication Status:

Published (in print/issue): 04/05/2020

DOI:

10.1108/IMDS-12-2019-0659

\section{Document Version}

Author Accepted version

\section{General rights}

Copyright for the publications made accessible via Ulster University's Research Portal is retained by the author(s) and / or other copyright owners and it is a condition of accessing these publications that users recognise and abide by the legal requirements associated with these rights.

\section{Take down policy}

The Research Portal is Ulster University's institutional repository that provides access to Ulster's research outputs. Every effort has been made to ensure that content in the Research Portal does not infringe any person's rights, or applicable UK laws. If you discover content in the Research Portal that you believe breaches copyright or violates any law, please contact pure-support@ulster.ac.uk. 


\section{Business Intelligence Systems and Operational Capability: An Empirical Analysis of High- \\ Tech Sectors}

\section{Purpose:}

In this research, we empirically examine the impact of Business Intelligence (BI) systems on operational capability in high-tech sectors. We also seek to understand the contextual factors that facilitate the adoption of BI systems.

\section{Design/Methodology/approach:}

We adopt Propensity Score Matching (PSM) and event study methodology, and analyze the financial data for a sample of 144 U.S. firms which adopted BI systems from 2005-2014, and compare them to control firms without BI systems.

\section{Findings:}

We find that the implementation of BI systems leads to higher operational capability, particularly for large high-tech firms with high technology intensity. We further show that R\&D intensity and firm size are important contextual factors for firms to reap the benefits of BI systems.

\section{Practical Implications:}

We demonstrate how benefits from the adoption of BI systems are likely to be strengthened. The benefits of BI systems depend on firms’ R\&D intensity and firm size of high-tech firms. Accessing relevant and timely reports for decision-making is particularly important in the highly dynamic, volatile and competitive high-tech sectors.

\section{Originality/Value:}

We contribute to the literature by providing empirical evidence that the adoption of BI systems can improve firms' operational capability and show that R\&D intensity and firm size are important 
contextual factors for firms to reap the benefits of BI systems. We advance the understanding regarding the contextual factors in which firms are more likely to gain additional benefits from their adoptions of BI systems.

Keywords: business intelligence systems; operational capability; R\&D intensity; firm size; hightech sector 


\section{Introduction}

In the fast-changing technology industry, business intelligence is considered as a powerful tool to improve operational capability (Lin and Kunnathur, 2019; Trieu 2017). Business intelligence (BI) systems leverage relevant information assets to facilitate fast and more informed decisions, significantly enhancing the effectiveness and efficiency of an organization (Agarwal and Dhar, 2014; Yeoh and Koronios, 2010). BI systems are defined as "analytical software and solutions for gathering, consolidating, analysing and providing access to information in a way that is supposed to let an enterprise's users make better business decisions" (Gangadharan and Swami, 2004, p. 140). However, successful implementation of BI systems is often difficult and requires a considerable amount of management commitment, expertise, and resources (Li et al., 2013; Yeoh and Koronios, 2010; Puklavec et al., 2018). It is a highly complex process that requires long-term commitment from the management and a vast amount of effort in developing appropriate organizational infrastructures, providing comprehensive training, and engaging stakeholders (Fuchs, 2006; Li et al., 2013; Moss and Atre, 2003; Watson et al., 2004). For example, the lack of organizational leadership hinders Kmart's efforts to fully deploy business analytical systems in the organization, leading to operational inefficiency and loss in the market (Liu et al., 2018). Therefore, there is much debate on the outcomes of BI systems in actual practice.

Operational capability refers to a firm's relative efficacy in transforming various operational resources (e.g., assets, equipment, employees, capitals...etc.) into useful organizational outputs (Li et al., 2010; Lam et al., 2016). It is the firm's ability to effectively deploy heterogeneous resources, skills, processes, and knowledge, enhancing productivity and operational effectiveness (Kumar et al., 1999; Peng et al., 2008; Swink and Harvey Hegarty, 1998). In a dynamic business 
environment, the ability to manage knowledge and information is crucial to the competitiveness of a firm. Although many organizations are making use of the advanced information technologies for decision-making and efficiency improvements, the actual impact of BI systems on the operational performance of firms in the fast-changing, dynamic environment is rarely investigated (Trieu, 2017). Operational capability represents a firm's ability to efficiently convey organizational resources into useful outputs, which is an abstract yet critical managerial competence of firms in a dynamic and competitive environment (Setia and Patel, 2013). Much research considers operational capability as an indicator for the overarching efficiency competence of firms in making use firm assets and resources (Lam et al., 2016). As a result, the use of operational capability changes best represents the possible beneficial outcomes in the adoption of BI systems. In addition, operational capability is particularly crucial for the high-tech sector because of its dynamism, uncertainty, and competitiveness. Specifically, for firms operating in a rapid-changing technology environment, agility, fast-adaptation, and quick response are critical for survival and prosperity (Gaulier et al., 2007; Lin et al., 2012; Silva, 2008). Due to their dynamic, uncertain and competitive operating nature, high-tech firms are often the pioneers in the adoption of administrative, operational, and information technology (IT) innovations.

In this research, we empirically examine the impact of BI systems on operational capability in the high-tech sector. We also seek to understand the contextual factors that facilitate the adoption of BI technologies. Given the importance of information management capability of firms and the significance of timely and effective handling of large volume of data (Lin and Kunnathur, 2019), it is surprising that little research has been carried out to investigate the impact of BI systems on the overall operating competence of firms, particularly in the dynamic, fast-changing high-tech 
sector (Park et al., 2017; Popovic et al., 2018; Trieu, 2017). Operational capability is a critical consideration particularly from an Operations Management (OM) perspective as it indicates the overall ability of firms to operate effectively, which is likely to be highly dependent on timely and reliable internal and external business data (Lam et al., 2016; Lin and Kunnathur, 2019). Accordingly, there are two major research questions in this study. First, does the adoption of BI systems enhance the managerial competence of firms as approximated by the changes in operational capability? If so, is the dynamism in the high-tech sector an important factor (i.e., moderator) driving the changes? We believe that our research is highly significant and relevant, given the availability of vast volume of internal and external data today. In fact, the high-tech industry is growing at a very high speed. It is considered to be one of the most profitable industries with vast investment opportunities (Hernandez et al., 2010) and is critical for the economic growth for many countries (Sims and O'Regan, 2010). Despite the importance of BI systems in the hightech sectors, research in this area remained limited. Our study fills this research gap. By developing the theoretical foundations and applying the Knowledge-based View (KBV) for integrating BI concepts into OM, our findings allow managers in the high-tech industry to understand the value of BI systems and the contextual factors which drive the business value of BI systems.

\section{Theoretical Background and Hypotheses Development}

\subsection{BI systems and Operational Capability}

The KBV of firms asserts that organizational knowledge is a unique, inimitable and strategic asset, leading to competitive outcomes of firms (Nonaka and Takeuchi, 1995). A firm's heterogeneous knowledge base can serve as a foundation to produce, renew, and reconfigure its resource base, leading to a dynamic capability and sustainable competitive advantage (Pemberton and Stonehouse, 
2000; Ranft and Lord, 2002; Wu, 2006). The KBV considers a firm as a knowledge-creating entity, which exists and survives through the creation and effective use of knowledge (Rebolledo and Nollet, 2011). As such, appropriate processes need to be in place in a firm to generate and transfer knowledge. Yet, knowledge diffusion in organizations is often difficult and inefficient due to the lack of appropriate infrastructure, and BI systems provide firms with a valuable opportunity for effective creation, diffusion and recombination of knowledge. From a knowledge-based perspective, the adoption of BI systems is a strategic initiative for gaining distinctive and competitive insights, developing firms' dynamic operational capabilities.

BI systems may also enhance the dynamic capability of firms. According to Teece et al. (1997), dynamic capability refers to a firm's ability for “adapting, integrating and reconfiguring internal and external organizational skills, resources, and functional competences to match the requirements of a changing environment (p. 515)." In fact, the role of BI systems for supporting knowledge management and operational improvements is well recognized (see, e.g., Park et al., 2017). Olszak (2014) coined the term "BI capability", which refers to an IT-enabled, analytical dynamic capability for enhancing decision-making competence and operational efficiency of firms (Mikalef et al., 2019). BI capability helps firms enhance sensing, seizing and transformational abilities such as the competence in identifying customer preferences, technological trends and structural changes in supply chains. Park et al. (2017) examined the role of BI and found BI technologies make organizations more agile and adaptive by enhancing their capability in detecting market opportunities and threats, and responding to technology transformations and competitors' moves, leading to a dynamic capability and superior performance outcome.

Equipped with data warehouse, data mining features, and online analytical procession (OLAP) technologies, BI systems are considered as an important organizational infrastructure for 
knowledge discovery, generation, and management. BI technologies retrieve vast quantities of internal and external data extracted from various sources, consolidating them to the metadata repository for multi-dimensional analyses (Trkman et al., 2010; Wang and Wang, 2008). BI systems shorten the time needed for transforming data into information and knowledge. Organizational members thus gain more timely access to operational data, identifying critical factors and making more informed decisions in a timely manner. Through BI systems, new organizational intelligence and business insights are generated, maximizing the value of firms' information and knowledge assets (Curko et al., 2007; Rao and Kumar, 2011). In particular, knowledge is fundamentally a power source for leveraging organizational resources, leading to superior operational capability and sustainable competitive advantage (Grant, 1996; Tippins and Sohi, 2003). With the adoption of BI systems, managers are sensibly informed in various aspects of their business and operations, improving resource allocations and making more reliable decisions, which eventually strengthen the operational capability of a firm. Thus, we propose the first hypothesis.

H1. Business intelligence systems lead to higher operational capability of high-tech firms.

\subsection{The Moderating Effect of Firm R\&D Intensity}

BI systems are particularly important in the high-tech sector because the industry stresses heavily on rapid new product developments through the incorporation of the most sophisticated technologies. Facilitated by BI systems, high-tech firms can more effectively derive relevant data into process and product knowledge, speeding up the R\&D activities, product launch and time to the market. BI systems provide high-tech firms with a powerful platform, making internal and 
external sources of data the valuable asset (Bose, 2009; Curko et al., 2007; Rao and Kumar, 2011). Specifically, BI systems enable high-tech firms to effectively capture dynamic market insights and customer preferences, strategically positioning themselves in a market with uncertain demand and short life cycles. Due to its dynamic and fast-changing nature, firms in the high-tech sectors often find it difficult to maintain their competitive advantages. Specifically, market uncertainty and technology volatility often make the demand for high-tech products difficult to forecast (Koh and Gunasekaran, 2006; Wu et al., 2005). With short product life cycles, condensed production leadtime, and changing process techniques, quality assurance can be an issue and efficient mass production is often difficult to achieve (Wu et al., 2005). These operational characteristics of the high-tech sector highlight the importance of BI systems in enhancing and coordinating product development, production, and marketing activities.

An emerging high-tech sector is characterized by high competitiveness with many new entries, making the use of BI systems more critical to gain a competitive edge. According to Malladi and Krishnan (2013), the extent of use of BI systems by firms increases as the competition intensifies and industry concentration decreases. In addition, the implementation of BI systems is often highly complex and requires specialized organizational knowledge and strong IT infrastructure (Baesens et al., 2016). Being in a knowledge-intensive industry, employees in the high-tech sectors are in a better position to leverage BI technologies (Lee et al., 2017). In addition, high-tech firms are also equipped with better IT skills and work more effectively in an IT-enabled organizational environment, further facilitating the knowledge sharing and information dissimilation among employees. In addition, high-tech firms are technologically complex, adding difficulty to decision making. BI systems collect and analyze multiple sources of information, 
which can significantly enhance the process of decision making and improve the related outcomes. In short, as the operations of high-tech firms are often more dynamic and employees in this type of firms are more ready to work in an IT-enabled environment, firms in the high-tech sectors are more likely to gain extra benefits from the adoption of BI systems (Lee et al., 2017; Ruigrok and Wagner, 2003).

H2. The positive impact of business intelligence systems on operational capability in the hightech firms is strengthened by R\&D intensity.

\subsection{The Moderating Effect of Firm Size}

The technology diffusion allows firms to streamline operations and improve workflows to improve efficiency (Tallon and Pinsonneault, 2011). Particularly, BI systems facilitate better coordination, communication, and cooperation across diverse business unit boundaries (Chen et al., 2012). Data and information are valuable organizational assets. Firms use analytics to capture data residing in different business levels and departments, and utilize the data to integrate the operations across different business units (Demirkan and Delen, 2013; Popovic et al., 2019). Firms with a large scale of operations across departments and geographical locations are richer in their data and information resources, developing a more unique and competitive knowledge base (Lee et al., 2017). Accordingly, large firms with diverse operations are likely to benefit more from the adoption of BI systems, making effective decisions across organizational boundaries and overcoming the bureaucracy because of the scale of its organization (Demirkan and Delen, 2013; Sahay and Ranjan, 2008). 
In addition, larger firms are likely to facilitate BI systems implementation because they have more resources in terms of human capital and expertise (Shah, 2003; Zhu et al., 2006). Adopting BI systems need technical and managerial resources, thus larger firms with resource advantage tend to implement new technology more effectively (Shefer and Frenkel, 2005). In short, larger firms tend to have richer, more sophisticated and wide-ranging data from the heterogeneous source (Dutta and Bose, 2015) and they possess more expertise and resources needed for BI systems assimilation. They thus are likely to acquire more benefits from the adoption of BI systems:

H3. The positive impact of business intelligence systems on operational capability gets strengthened in large high-tech firms.

\section{Methodology}

\subsection{Sample selection and Data Collection}

We focus on the U.S.-listed manufacturing firms in the high-technology sector (SIC codes: 2834, 3511-3599, 3612-3699, and 3812-3873) (e.g., Modi and Mishra, 2011). The purpose of this research is to examine the impact of BI systems in a dynamic and competitive environment and high-tech sector provides an appropriate setting for this study (Mikalef et al., 2019). In particular, U.S. firms are the pioneers in adopting business analytical technologies (Lin and Kunnathur, 2019) and the U.S. stock market provides comprehensive financial information for empirical analysis. Also, the high-tech sector provides a distinctive research setting to examine the competitive position of firms in a fast-changing, dynamic environment. The sample was taken from 2005 to 2014, when the BI systems became more mature and widely adopted (Teo et al., 2016; Yiu et al., 2018). BI systems are a set of well-defined, specific software for consolidating, analyzing and 
presenting organizational data. Based on the annual vendor list of Gartner Inc., a worldwide leading research and advisory company in information technology, we can clearly identify the providers of BI systems and BI software. Following previous studies in this area, we focus on news announcements (Elbashir et al., 2008; Rubin and Rubin, 2013; Teo et al., 2016) about the adoption of BI systems. According to Gartner Inc., the market leaders for BI solutions are Cognos, IBM, Business Objects, Hyperion, Information Builders, Oracle, Microsoft, QlikTech, MicroStrategy, Tableau, Tibco Spotfire, SAP, and SAS. These market-leading BI vendors occupy nearly $65 \%$ of the market while the remaining $35 \%$ is occupied by over a thousand small BI vendors (Teo et al., 2016; Yiu et al., 2019). Our keyword search is based on the combinations of names of these major BI solution providers as listed by Gartner Inc. and other critical terms such as "Business Intelligence" or "BI systems" (Yiu et al., 2018).

More specifically, to identify a firm with the use of BI systems, we search news announcements based on some keywords, including the names of the U.S.-listed firms, the list of the market-leading BI vendors, "business intelligence systems" or "BI systems" together with "adoption", "introduce", or "implementation" in the comprehensive Factiva database for global business news (Yiu et al., 2018). We focus on the first announcement of BI systems adoption to avoid overlapping effects that could show bias our in statistics (Corbett et al., 2005; Hendricks and Singhal, 2008; Naveh and Marcus, 2005). Also, we eliminate announcements that are irrelevant to BI adoption such as mergers and acquisitions of another firm to develop in-house BI systems and the executive appointments for initiating BI projects. We attach an example in the Appendix 1.

There are two phases of BI systems implementation. The first phase involves the installation of business intelligence software, the prototype development, and the combining of data sources 
within an organization (Gangadharan and Swami, 2004; Zeng et al., 2006). The second phase of BI implementation is about the system's deployments (Gangadharan and Swami, 2004; Zeng et al., 2006). To facilitate the deployment of BI systems, firms need to provide extensive guidance and training on how to use BI systems to perform analyses and make necessary adjustments to achieve the full adoption of BI systems in operations (Gangadharan and Swami, 2004; Olexova, 2014; Zeng et al., 2006). Accordingly, a full adoption of BI in this study indicates that a firm has completely implemented and integrated BI applications into its operational systems, as well as provided user training in major functional areas. It usually takes 6-18 months (average length at one year) to reach the full adoption of BI into daily operations (Horakova and Skalska, 2013; Olexova, 2014; Zeng et al., 2006).

In this study, we take the whole event period as the time interval during which BI software is being implemented to achieve a full adoption. We take the year of full BI systems' adoption as year $t$. One year immediately prior to the BI systems' adoption is taken as year $t-1$. Two years prior the BI systems' adoption as the base year (year $t-2$ ) to determine the control firms. The year following the event year $t+1$ is used to test the impact of the adoption of BI systems. Thus, we examine the abnormal operational capability over the event period (years $t-2$ through $t+1$ ).

\subsection{Measurements}

Operational capability. We use the stochastic frontier estimation (SFE) methodology to measure the operational capability regarding a firm's efficiency to transform organizational resources into operating income in comparison with its industry peers (Carmel and Sawyer, 1998; Dutta et al., 2005; Li et al., 2010). Specifically, we use the frontier function in Equation (1) to consider the 
organizational resources, including number of employees, capital expenditure, and cost of goods sold.

From a perspective of the traditional operations management, the SFE is a better approach to measure a firm's operational capability. SFE generates a relative measure of operational capability based on the transformative efficiency of converting organizational resources into operating income in the same industry sector (Eroglu and Hofer, 2011). Also, SFE incorporates a composite error term composed of random effects and pure inefficiency to avoid the influence from random factors and possible upward bias of inefficiency (Vandaie and Zaheer, 2014). $\ln (\text { Operating income })_{i j t}=\beta_{0}+\beta_{1} \ln$ (Number of employees $)_{i j t}$

$$
\begin{aligned}
& +\beta_{2} \ln (\text { Capital expenditure })_{i j t} \\
& +\beta_{3} \ln (\text { Cost of goods sold })_{i j t}+\varepsilon_{i j t}-\gamma_{i j t}
\end{aligned}
$$

where $\varepsilon_{i j t}$ is the purely stochastic random error term affecting operating income, and $\gamma_{i j t}$ captures the operational inefficiency of a firm $i$ in industry $j$ (2-digit SIC codes) in year $t . \gamma_{i j t}$ ranges from 0 to 1 , with 0 meaning no operational inefficiency relative to the industry peers. Thus, $\gamma_{i j t}$ is a relative measure to indicate how inefficient a firm is in comparison with a corresponding frontier in the same industry and in the same year. The composite error term, $\left(\varepsilon_{i j t}-\gamma_{i j t}\right)$ is estimated based on the difference between the maximum achieved operating income in an industry and the observed operating income to obtain a consistent estimate of firm-specific operational inefficiency, $\hat{\gamma}_{i j t}$. Hence, the operational capability of a firm $i$ in industry $j$ in year $t$ is Operating capability $_{i j t}=\left(1-\hat{\gamma}_{i j t}\right) \times 100 \%$ 
$R \& D$ intensity. $\mathrm{R} \& \mathrm{D}$ intensity refers to the level and strength of firms' $\mathrm{R} \& \mathrm{D}$ activities. We calculate $R \& D$ intensity as a ratio of $R \& D$ expenditures to sales (Lo et al., 2013).

Size. Size refers to firm size which is measured as the natural logarithm of total assets (Liu et al., 2014).

\subsection{Endogeneity and Propensity Scores Matching}

In this study, we compare the performance of BI-adopting firms (i.e., sample firms) versus nonBI-adopting firms (i.e., control firms) from the base year to one year after full adoption. As the BI adoption might be related to some endogenous factors, there is potential self-selection bias and endogeneity issues when we compare sample firms with control firms (Li and Prabhala, 2007). For example, firms with strong management skills and IT infrastructure are more likely to

implement BI systems and also more likely to have higher operational capability (Trieu, 2017). Yet, these issues can be solved by applying the propensity scores matching (PSM) method (e.g., Nanda and Ross, 2012).

We employ the PSM using one-to-one nearest neighbor matching based on individual propensity scores. The propensity score is a probability of a firm to adopt BI under the influence of some firm-specific factors (e.g., Austin, 2011; Dehejia and Wahba, 2002). We choose some pre-treatment factors in year $t-2$ that might influence a firm to adopt BI. Because having too many firm-specific factors would affect the matching quality (Dehejia and Wahba, 2002), we select a few major firm characteristics that are likely to co-vary with the adoption of BI systems. We consider size, organizational slack, sales growth, labor productivity, leverage, and age of firms. 
Large firms are more likely to adopt BI systems (Damanpour, 1991) due to their financial strengths and operational complexity. According to previous studies (e.g., Lawson, 2001), organizational slack is a buffer resource that allows firms to adapt to technological changes in business activities more readily. A high sales growth environment might encourage the management to use BI systems to access quality information in the market and support new product development (Chae et al., 2014). Firms with higher labor productivity might tend to adopt any organizational innovations, including BI systems (Evans and Davis, 2005). A higher level of financial leverage might cause firms to be less flexible in response to unexpected changes in their cash flows, leading to more hesitation in investing in BI systems (Denis, 2011; Malshe and Agarwal, 2015). Older firms are likely to be more mature in their management skills and have more experience, which enhances organizational ability to identify and pursue further technological advancements (Sørensen and Stuart, 2000).

We obtained 282 sample firms in the manufacturing industry, and among these firms a total of 144 firms belong to the high-tech sector according to a commonly well-accepted classification based on SIC codes (see e.g., Modi and Mishra, 2011). We attach the distribution of sample firms across industries and by adoption years in Appendices 2 and 3, respectively. We consider both industry dummies (2-digit SIC codes) and year dummies. We measure size as the natural logarithm of total assets (Liu et al., 2014), organizational slack as the ratio of the difference between current assets and current liabilities to total assets (Luo et al., 2016), sales growth as the annual sales growth rate (Luo et al., 2013), labor productivity as the ratio of operating income to the number of employees (Lo et al., 2013), leverage as the ratio of total debts to total assets (Luo et al., 2013), and age as the natural logarithm of the number of years from the date of incorporation (Zhang, 2015). We assign 
1 to sample firms with BI systems adoption and 0 to control firms without BI systems adoption. We attach the details of variables and their corresponding measurements, data sources, and references in Appendix 4.

Table 1 presents the PSM results. The section on the summary of balance for all the data shows the mean differences (Mean Diff) between the sample and control firms before matching. For example, the difference is 1.44 in size, 28.30 in labor productivity, and 0.19 in age. After matching, the Mean Diff reduces significantly, as shown in the section on the summary of balance for matched data. For example, the Mean Diff in size becomes -0.10 , labor productivity becomes -3.71, and age becomes 0.04 . Thus, the sample and control firms after the matching are similar in terms of size, organizational slack, sales growth, labor productivity, leverage, and age. Specifically, the percentages of improvement for the firm-specific factors that are significantly different between the sample and control firms before matching (i.e., size, sales growth, labor productivity, and age) ranges from $65.4 \%$ to $92.9 \%$. All these factors are insignificantly different after matching.

Insert Table 1 about here

We apply the event-study methodology to examine the impact of BI adoption on the abnormal operational capability of firms. Following Barber and Lyon (1996), we measure the abnormal operational capability in Equations (3) and (4)

$$
\begin{gathered}
\mathrm{AOC}_{i, t+k}=\mathrm{OCS}_{i, t+k}-\mathrm{E}\left[\mathrm{OCS}_{i, t+k}\right] \\
\mathrm{E}\left[\mathrm{OCS}_{i, t+k}\right]=\mathrm{OCS}_{i, t+\tau}+\left(\mathrm{OCC}_{i, t+k}-\mathrm{OCC}_{i, t+\tau}\right)
\end{gathered}
$$

where $\mathrm{AOC}_{i, t+k}$ is the abnormal operational capability of a sample firm $i$ in period $t+k$. OCS $i, t+k$ is the operational capability of a sample firm $i$ in period $t+k$ and $\mathrm{OCC}_{i, t+k}$ is the operational 
capability of a control firm $i$ in period $t+k$. E $\left[\mathrm{OCS}_{i, t+k}\right]$ is the expected operational capability of a sample firm $i$ in any period $t+k$, using $k$ as the ending year of comparison $k=(-1,0,1)$ and $\tau$ as the base year $(\tau=-2)$.

\subsection{Cross-sectional Regression Analysis}

We examine R\&D intensity $(H 2)$ and firm size $(H 3)$ that may have moderating impacts on the abnormal changes in operational capability. According to the previous studies (Hendricks and Singhal, 2008), we use a cross-sectional regression analysis through estimating a regression model as Equation (5) below to examine how firm size and R\&D intensity affect the cumulative abnormal operational capability (CAOC) that is the sum of abnormal OC from year $t-2$ to $t+1$. In this regression model, we consider six control variables, including age, leverage, year of BI adoption, industry sales growth, industry competitiveness and control for the persistent influence of operational capability as previous operational capability (Vandaie and Zaheer, 2014).

$$
\begin{aligned}
\text { CAOC }_{i}= & \beta_{0}+\beta_{1}(\text { Previous operational capability })_{i}+\beta_{2}(\text { Year of BI adoption })_{i} \\
& +\beta_{3}(\text { Age })_{i}+\beta_{4}(\text { Leverage })_{i}+\beta_{5}(\text { Industry sales growth })_{i} \\
& +\beta_{6}(\text { Industry competitiveness })_{i}+\beta_{7}(\text { R\&D intensity })_{i}+\beta_{8}(\text { Size })_{i}+\varepsilon_{i}
\end{aligned}
$$

where $i$ refers to the $i$ th sample firm. $\mathrm{CAOC}_{i}$ is the cumulative abnormal operational capability of firm $i$ over the period from years $t-2$ to $t+1$. All control variables are in year $t-2$. Size and R\&D intensity are in the event year $t$.

We measure age as the natural logarithm of the number of years from the date of firm's incorporation and leverage as the ratio of total debts to total assets. As a more competitive 
environment of fast-growing industries might require stronger business analytical capacity, making BI systems more important to invest (Mendelson, 2000). Based on the 2-digit SIC codes, we calculate industry sales growth as a yearly change in sales in an industry (Hendricks and Singhal, 2008) and industry competitiveness as the total of squared market shares of firms in an industry (Lo et al., 2013).

\section{Results}

Table 2 presents the descriptive statistics of the operational capability for the sample and control firms before the adoption of BI systems. We conduct the $t$-test and the statistical result shows that the mean difference of operational capability between the sample and control firms at the base year (i.e., year $t-2)$ are insignificantly different from zero $(p>0.1)$.

Insert Table 2 about here

\subsection{Results of the Event Study Analysis}

We test the hypotheses and examine whether the operational capability significantly increases through the adoption of BI systems. Table 3 presents the statistical results which provide insights into the patterns of the abnormal operational capability over time. The whole event period consists of three phases, year $t-2$ (the base year) to year $t-1$, year $t-1$ to year $t$, and year $t$ to year $t+1$, where $t$ is the year that the sample firms have fully adopted BI systems. $N$ is the sample size in each time phase. The sample size gradually decreases due to the unavailability of longitudinal data. Our discussion below mainly focuses on the non-parametric Wilcoxon signed-rank (WSR) test results based on Barber and Lyon's (1996) view where they stated that the WSR test is more powerful than the parametric $t$-test. Yet, for completeness, we also present the sign test and $t$-test results. 
As shown in Table 3, there is no abnormal increase in the operational capability in the implementation period of business intelligence software (i.e., year $t-2$ to year $t-1, p>0.1$ ). Yet, the abnormal increase in the operational capability is marginally significant just after the firms have fully adopted BI systems in the year $t$ (i.e., year $t-1$ to year $t, p<0.1$ ) and the abnormal operational capability significantly increases in the following year (i.e., year $t$ to year $t+1, p<0.05$ ). Thus, Hypothesis 1 is supported. The cumulative results indicate that from the base year leading up to the year with full adoption of BI systems (i.e., year $t-2$ to year $t$ ), the abnormal increase in the operational capability is insignificant $(p>0.1)$. While comparing the base year with the year after the full use of BI systems within an organization (i.e., year $t$-2 to year $t+1, p<0.1$ ), we find a significant increase in operational capability. Overall, firms achieve significant improvement in operational capability with BI systems adoption.

\section{Insert Table 3 about here}

\subsection{Self-selection Bias and Endogeneity Concern}

We employ the PSM by considering several firm-specific factors that are likely to influence a firm in its adoption of BI systems to control for the self-selection bias and endogeneity problems. According to Table 1, the PSM matches the sample and control firms effectively. Our PSM procedures help reduce some selection bias and endogeneity concerns.

\subsection{Results of the Regression Analysis}

We further conduct regression analysis to test the moderating effects of R\&D intensity and size of firms on the cumulative abnormal operational capability from year $t-2$ to year $t+1$. 
Table 4 shows the correlations of the study variables. Table 5 presents the regression analysis results in four models. Model 1 considers the estimation with the intercept and control variables. Models 2 and 3 report the moderating impacts of R\&D intensity and size, respectively. Model 4 represents the full model. All models are significant according to the $F$-statistics $(p<0.05$ in Model 1; $p<0.01$ in Models 2-4).

In Table 5, the moderating effect of R\&D intensity of firms with BI systems is positively related to abnormal operational capability as shown in Model $3(p<0.1)$ and Model $4(p<0.05)$, indicating that higher technology-intensive firms obtain larger improvement in operational capability. Thus, Hypothesis 2 is supported. Having the variable of R\&D intensity in the model improves the explanatory power of the regression models because of the increase in the adjusted R-squared from $9.44 \%$ to $10.71 \%$. Likewise, the moderating effect of firm size is significantly positive for abnormal operational capability in Models 2 and $4(p<0.05)$, suggesting that larger firms increase operational capability further with the adoption of BI systems. Thus, Hypothesis 3 is supported. Adding the variable of firm size in the model improves the explanatory power of the regression models as indicated by the increase of the adjusted R-squared from $9.44 \%$ to $13.09 \%$.

The control variable regarding previous operational capability of firms is significantly negative $(p<0.01)$ to the corresponding abnormal operational capability, indicating that firms with low operational capability before BI systems adoption can benefit from higher operational improvement after BI adoption than firms with high operational capability before BI adoption. Another control variable, age, is positively significant $(p<0.1)$ in Model 3 in Table 5, suggesting that older firms with the full adoption of BI systems obtain higher operational capability. 
Insert Table 4 about here

Insert Table 5 about here

Compared with control firms, sample firms enhance their operational capability significantly right after they have adopted BI systems, i.e., year $t$, and in the year immediately after adoption of BI systems, i.e., year $t+1$. As shown in Table 3, the median (mean) increase in operational capability is $2.73 \%(4.01 \%)$, with nearly $52 \%$ of firms experiencing improvements in their operational capability in the year of BI adoption. Furthermore, the median (mean) of changes in operational capability increases to $4.01 \%(6.09 \%)$, with nearly $56 \%$ of firms experiencing positive change in operational capability in the year after the adoption of BI systems. The median (mean) increase in the operational capability is $8.27 \%(11.04 \%)$, with nearly $56 \%$ of firms are experiencing improvement in their operational capability from the base year to the year after the adoption of BI systems.

\section{Discussion}

We empirically examine the impacts of the adoption of BI systems on the operational capability of high-tech firms. Based on an event study analysis of financial data for a sample of 144 cases on the adoptions of BI systems from 2005-2014 in the U.S., we find that the implementation of BI systems leads to higher operational capability, and this is especially the case for large firms in a high R\&D intensive setting. We contribute to the literature by providing empirical evidence that the adoption of BI systems can improve firms' operational capability and show that R\&D intensity and firm size are important contextual factors for firms to reap the benefits of BI systems. We advance the understanding regarding the contextual factors in which firms are more likely to gain 
additional benefits from their adoptions of BI systems. We discuss further the theoretical and practical implications below.

\subsection{Theoretical Implications}

BI systems differ from information systems by having analytical techniques to discover and multidimensionally analyze hidden patterns in large amounts of data (Wang and Wang, 2008). While knowledge is useful in general, having relevant and impactful informational insights provides higher value to firms (Liu et al., 2014). Through BI applications, valuable business insights is created to support decision-making, increasing the information value of data resided in the database (Curko et al., 2007; Herschel and Jones, 2005). In particular, much literature emphasizes that data, information and operational insights are one of the most valuable strategic resource that confers firm competitiveness (e.g., Craighead et al., 2009; Nonaka and Takeuchi, 1995; Ranft and Lord, 2002). Business information and intelligence is a fundamental resource to develop organizational capabilities (Grant, 1996; Lee and Hong, 2002; Tippins and Sohi, 2003).

Scholars in OM have long realized that activity residing in organizational capabilities and routines lead to competitive advantages. Yet, the effects of BI systems on operational capability in the high-tech sector have not been widely examined. The KBV pinpoints the importance of organizational knowledge in enhancing the competitiveness of firms (Grant 1996; Lin et al., 2012). However, how data and knowledge are developed and supported by BI systems have not been extensively investigated. Taking the KBV for competitive outcomes of BI systems, we postulate and demonstrate that business analytical technologies help improve the operational capability of firms particularly in the technology intensive sectors. We contribute to the understanding of KBV by highlighting how R\&D and technology competition intensify the importance of knowledge, 
making data analytics more critical in enhancing competitiveness of firms (Lin et al., 2012; Liu et al., 2014). Specifically, we show that the dynamic characteristic of the technology sector is a critical driving factor making the KBV more salient (Liu et al., 2014; Mikalef et al., 2019).

\subsection{Managerial Implications}

Our research contributes some important practical implications as firms in the high-tech sectors are uncertain about the business value of BI systems. The implementation of BI systems requires large investments in infrastructure and resources over a long period of time, and there are many challenges in this process that have caused more than half of the projects for BI systems to fail during implementation (Goasduff, 2015; Yeoh and Koronios, 2010). Our results show that the adoption of BI systems leads to higher operational capability of high-tech firms. In particular, we further demonstrate how such benefits from the adoption of BI systems are likely to be strengthened. The benefits of BI systems depend on firms' R\&D intensity and firm size of hightech firms, not on the BI systems alone. In the fast development of "big data" and under information-intensive competition, high-tech firms need to consider how the competitive outcomes from the adoption of BI systems can be strengthened and sustained.

Firms today need to manage vast amounts of business data available in various internal and external sources. High-tech firms need to enhance their KM capability by deploying BI systems to support wider organizational activities. For example, BI systems enable operations managers to track and collect more data easily from supply chains. By increasing the visibility and transparency of the process from order and material procurement to production and delivery, operations managers might gain more comprehensive insights from asset utilization to productivity and 
equipment deployment, while also tracking resources' availability, detecting quality problems, and ensuring an efficient manufacturing process (Elbashir et al., 2008). Accessing relevant and timely reports for decision-making is particularly important in the highly dynamic, volatile and competitive high-tech sectors.

\section{Conclusions}

Successful adoption of BI systems is vital for firms to derive values from their data, particularly in the internet era where valuable insights can be derived from properly analyzing and sharing huge amounts of data. However, empirical evidence on the business value of BI systems in the high-tech sectors, particularly their impact on operational capability, is limited. Also, little is known regarding the contextual factors in the adoption of BI systems in the high-tech sectors. Based on the event study analysis on the adoption of BI technologies in the U.S., we find that the adoption of BI systems leads to higher operational capability. We find that the impacts of BI systems adoption on the operational capability are significantly improved, more so for firms with higher R\&D intensity and large firm size. We take the KBV on the competitive outcomes of BI systems. With the availability of large amount of data nowadays, firms can make use of BI systems to enhance their industry and organizational information flows, leading to a higher operational capability. Our study provides empirical evidence that high-tech firms can achieve a higher competitive advantage from the adoption of BI systems.

There are some limitations in this research. First, we classify whether a firm belongs to the high-tech sector or not based on the SIC code (see e.g., Modi and Mishra, 2011). However, we understand that the level of technology within the industries can also vary significantly. Second, 
like many other research studies based on secondary data, we determine if a firm adopted BI systems based on their own announcements. The level and extensiveness of their BI implementations cannot be accurately assessed by our secondary data.

For future studies, researchers can compare the benefits of BI systems in analyzing structured versus unstructured data. BI systems mainly revolve around the analysis of structured and unstructured data (Baars and Kemper, 2008). Structured data are usually classified by the nature of their field, for example, financial, production, and logistics. For instance, operations managers can get an instantaneous analysis through BI systems on whether their inventories are aligned with market demand patterns by capturing data from the inventory and orders records. Unstructured data are more complex and include data found in emails, social media platforms, and business interactions. For example, marketing managers can understand more about customer experience using BI systems. They can analyze data from their customer service platform on Twitter to get potential product trends and support their marketing strategy decisions. BI systems that are used to capture and analyze the hidden patterns in unstructured data might allow a firm to gain a better position and generate competitive outcomes because unstructured data can provide profound insights that are more difficult to be imitated from a KBV. Further research can explore this, enhancing our understanding of a knowledge-based advantage using BI systems.

\section{Acknowledgements:}


We thank the review team for their many helpful comments on earlier versions of our paper. This research was supported in part by the University Grants Council of Hong Kong under grant number 155009/15B.

\section{References}

Agarwal, R., Dhar, V. (2014), "Big data, data science, and analytics: The opportunity and challenge for IS research", INFORMS.

Austin, P. C. (2011), "An introduction to propensity score methods for reducing the effects of confounding in observational studies", Multivariate Behavioral Research, Vol. 46, pp. 399424.

Baars, H., Kemper, H. G. (2008), "Management support with structured and unstructured dataan integrated business intelligence framework", Information Systems Management, Vol. 25 No. 2, pp. 132-148.

Barber, B. M., Lyon, J .D. (1996), "Detecting abnormal operating performance: The empirical power and specification of test statistics", Journal of Financial Economics, Vol. 41, pp. 359399.

Baesens, B., Bapna, R., Marsden, J. R., Vanthienen, J., Zhao, J. L. (2016), "Transformational issues of big data and analytics in networked business", MIS Quarterly, Vol. 40 No. 4.

Bose, R. (2006), "Understanding management data systems for enterprise performance management". Industrial Management \& Data Systems, Vol. 106 No. 1, pp. 43-59.

Carmel, E., Sawyer, S. (1998), "Packaged software development teams: what makes them different?", Information Technology \& People, Vol. 11, pp. 7-19.

Chae, B. K., Yang, C., Olson, D., Sheu, C. (2014), "The impact of advanced analytics and data accuracy on operational performance: A contingent resource based theory (RBT) perspective", Decision Support Systems, Vol. 59, pp. 119-126.

Chen, H., Chiang, R. H., Storey, V. C. (2012), "Business intelligence and analytics: from big data to big impact", MIS Quarterly, pp. 1165-1188.

Corbett, C. J., Montes-Sancho, M. J., Kirsch, D. A. (2005), "The financial impact of ISO 9000 certification in the United States: An empirical analysis", Management Science, Vol. 51, pp. 1046-1059. 
Craighead, C. W., Hult, G. T. M., Ketchen, D. J. (2009), "The effects of innovation-cost strategy, knowledge, and action in the supply chain on firm performance", Journal of Operations Management, Vol. 27, pp. 405-421.

Curko, K., Bach, M. P., Radonic, G. (2007), "Business intelligence and business process management in banking operations, Information Technology Interfaces" in 29th International Conference on IEEE, pp. 57-62.

Damanpour, F. (1991), "Organizational innovation: A meta-analysis of effects of determinants and moderators", Academy of Management Journal. Vol. 34, pp. 555-590.

Dehejia, R. H., Wahba, S. (2002), "Propensity score-matching methods for nonexperimental causal studies", The Review of Economics and Statistics, Vol. 84, pp. 151-161.

Demirkan, H., Delen, D. (2013), "Leveraging the capabilities of service-oriented decision support systems: Putting analytics and big data in cloud", Decision Support Systems, Vol. 55 No. 1, pp. 412-421.

Denis, D. J. (2011), "Financial flexibility and corporate liquidity", Journal of Corporate Finance, Vol. 17, pp. 667-674.

Dutta, S., Narasimhan, O., Rajiv, S. (2005), "Conceptualizing and measuring capabilities: Methodology and empirical application", Strategic Management Journal, Vol. 26, pp. 277285.

Elbashir, M. Z., Collier, P. A., Davern, M. J. (2008), "Measuring the effects of business intelligence systems: The relationship between business process and organizational performance", International Journal of Accounting Information Systems, Vol. 9, pp. 135153.

Eroglu, C., Hofer, C. (2011), "Lean, leaner, too lean? The inventory-performance link revisited", Journal of Operations Management, Vol. 29, pp. 356-369.

Evans, W. R., Davis, W. D. (2005), "High-performance work systems and organizational performance: The mediating role of internal social structure", Journal of Management, Vol. 31 No. 5, pp. 758-775.

Fuchs, G. (2006), The vital BI maintenance process. Business Intelligence Implementation: Issues and Perspectives, Hyderabad. 
Gangadharan, G. R., Swami, S. N. (2004), "Business intelligence systems: design and implementation strategies", in Information Technology Interfaces, 2004. 26th International Conference on. IEEE, pp. 139-144.

Gaulier, G., Lemoine, F., Ünal-Kesenci, D. (2007), "China’s integration in East Asia: Production sharing, FDI \& high-tech trade", Economic Change and Restructuring, Vol. 40, pp. 27-63.

Goasduff, L. (2015), "Gartner Says Business Intelligence and Analytics Leaders Must Focus on Mindsets and Culture to Kick Start Advanced Analytics", available at: https://www.gartner.com/en/newsroom/press-releases/2015-09-15-gartner-says-businessintelligence-and-analytics-leaders-must-focus-on-mindsets-and-culture-to-kick-startadvanced-analytics/ (assessed 20 March 2018).

Grant, R. M. (1996), "Toward a Knowledge-Based Theory of the firm", Strategic Management Journal, Vol. 17, pp. 109-122.

Hendricks, K. B., Singhal, V. R. (2008), "The effect of product introduction delays on operating performance", Management Science, Vol. 54, pp. 878-892.

Hernandez, B., Jimenez, J., José Martin, M. (2010), "Business management software in high-tech firms: the case of the IT services sector", Journal of Business \& Industrial Marketing, Vol. 25, pp. 132-146.

Herschel, R. T., Jones, N. E. (2005), "Knowledge management and business intelligence: the importance of integration". Journal of Knowledge Management, Vol. 9, pp. 45-55.

Horakova, M., Skalska, H. (2013), "Business Intelligence and Implementation in a Small Enterprise", Journal of Systems Integration, Vol. 4, pp. 50.

Koh, S. L., and Gunasekaran, A. (2006), "A knowledge management approach for managing uncertainty in manufacturing", Industrial Management \& Data Systems, Vol. 106 No. 4, pp. 439-459.

Kumar, V., Kumar, U., Persaud, A. (1999), "Building technological capability through importing technology: the case of Indonesian manufacturing industry", The Journal of Technology Transfer, Vol. 24, pp. 81-96.

Lam, H. K., Yeung, A. C., \& Cheng, T. E. (2016). The impact of firms' social media initiatives on operational efficiency and innovativeness. Journal of Operations Management, Vol. 47, pp. $28-43$. 
Lawson, M. B. (2001), "In praise of slack: Time is of the essence", The Academy of Management Executive, Vol. 15, pp. 125-135.

Lee, S. M., Hong, S. (2002), "An enterprise-wide knowledge management system infrastructure", Industrial Management \& Data Systems, Vol. 102 No.1, pp. 17-25.

Lee, H., Kweon, E., Kim, M., Chai, S. (2017), "Does Implementation of Big Data Analytics Improve Firms' Market Value? Investors' Reaction in Stock Market", Sustainability, Vol. 9, pp. 978.

Li, S., Shang, J., Slaughter, S. A. (2010), "Why do software firms fail? Capabilities, competitive actions, and firm survival in the software industry from 1995 to 2007", Information Systems Research, Vol. 21, pp. 631-654.

Li, K., Prabhala, N. R. (2007), Self-selection Models in Corporate Finance, the Handbook of Corporate Finance: Empirical Corporate Finance, North-Holland, Amsterdam.

Li, X., Hsieh, J. P. A., Rai, A. (2013), "Motivational differences across post-acceptance information system usage behaviors: An investigation in the business intelligence systems context", Information Systems Research, Vol. 24, pp. 659-682.

Lin, R. J., Che, R. H., Ting, C. Y. (2012), "Turning knowledge management into innovation in the high-tech industry", Industrial Management \& Data Systems, Vol. 112 No. 1, pp. 42-63.

Lin, C., Kunnathur, A. (2019). Strategic orientations, developmental culture, and big data capability. Journal of Business Research, Vol. 105, pp. 49-60.

Liu, X., Yeung, A. C., Lo, C .K., Cheng, T. (2014), "The moderating effects of knowledge characteristics of firms on the financial value of innovative technology products", Journal of Operations Management, Vol. 32, pp. 79-87.

Liu, Y., Han, H., DeBello, J. (2018) "The challenges of business analytics: successes and failures" Proceedings of the 51th Hawaii International Conference on Systems Sciences, pp. 840-849.

Lo, C. K., Wiengarten, F., Humphreys, P., Yeung, A. C., Cheng, T. (2013), "The impact of contextual factors on the efficacy of ISO 9000 adoption", Journal of Operations Management, Vol. 31, pp. 229-235.

Luo, X., Kanuri, V. K., Andrews, M. (2014). "How does CEO tenure matter? The mediating role of firm-employee and firm-customer relationships", Strategic Management Journal, Vol. 35, pp. 492-511. 
Luo, B., Luo, C., Ge, J., Zhang, D. (2016). "The moderating effects of slack on the relationship between ambidextrous strategy and performance: Evidence from high-tech firms in China", Journal of Business Economics and Management, Vol. 17, pp. 734-748.

Malladi, S., Krishnan, M. (2013), "Determinants of usage variations of business intelligence \& analytics in organizations-an empirical analysis", in Thirty Fourth International Conference on Information Systems, Milan, 2003.

Mikalef, P., Krogstie, J., Pappas, I. O., \& Pavlou, P. (2019). Exploring the relationship between big data analytics capability and competitive performance: The mediating roles of dynamic and operational capabilities. Information \& Management, In Press

Malshe, A., Agarwal, M. K. (2015), "From Finance to Marketing: The Impact of Financial Leverage on Customer Satisfaction", Journal of Marketing, Vol. 79, pp. 21-38.

Mendelson, H. (2000), "Organizational architecture and success in the information technology industry", Management Science, Vol. 46, pp. 513-529.

Modi, S. B., Mishra, S. (2011), "What drives financial performance-resource efficiency or resource slack?: Evidence from US based manufacturing firms from 1991 to 2006", Journal of Operations Management, Vol. 29 No. 3, pp. 254-273.

Moss, L. T., Atre, S. (2003), Business intelligence roadmap: the complete project lifecycle for decision-support applications, Addison-Wesley Professional.

Nanda, A., Ross, S. L. (2012), "The impact of property condition disclosure laws on housing prices: Evidence from an event study using propensity scores", The Journal of Real Estate Finance and Economics, Vol. 45, pp. 88-109.

Naveh, E., Marcus, A. (2005), "Achieving competitive advantage through implementing a replicable management standard: Installing and using ISO 9000", Journal of Operations Management, Vol. 24, pp. 1-26.

Nonaka, I., Takeuchi, H. (1995), The knowledge-creating company: How Japanese companies create the dynamics of innovation. Oxford university press.

Olexova, C. (2014), "Business intelligence adoption: a case study in the retail chain", WSEAS Transactions on Business and Economics, Vol. 11, pp. 95-106.

Olszak, C. M. (2014). Towards an understanding Business Intelligence. A dynamic capabilitybased framework for Business Intelligence. In 2014 Federated Conference on Computer Science and Information Systems. IEEE. pp. 1103-1110. 
Park, Y., El Sawy, O. A., Fiss, P. (2017). The role of business intelligence and communication technologies in organizational agility: a configurational approach. Journal of the association for information systems, Vol. 18, No. 9, pp. 648-686.

Pemberton, J. D., Stonehouse, G. H. (2000), "Organisational learning and knowledge assets-an essential partnership", The Learning Organization, Vol. 7, pp. 184-194.

Peng, D. X., Schroeder, R. G., Shah, R. (2008), "Linking routines to operations capabilities: A new perspective", Journal of Operations Management, Vol. 26, pp. 730-748.

Popovič, A., Puklavec, B., Oliveira, T. (2019). Justifying business intelligence systems adoption in SMEs. Industrial Management \& Data Systems. Vol. 119, No. 1, pp. 210-228.

Puklavec, B., Oliveira, T., \& Popovič, A. (2018). Understanding the determinants of business intelligence system adoption stages. Industrial Management \& Data Systems. Vol. 118, No. 1, pp. 236-261.

Ranft, A. L., Lord, M. D. (2002), "Acquiring new technologies and capabilities: A grounded model of acquisition implementation", Organization Science, Vol. 13, pp. 420-441.

Rao, G. K., Kumar, R. (2011), "Framework to integrate business intelligence and knowledge management in banking industry", Review of Business and Technology Research.

Rebolledo, C., Nollet, J. (2011), "Learning from suppliers in the aerospace industry", International Journal of Production Economics, Vol. 129 No. 2, pp. 328-337.

Rubin, E., Rubin, A. (2013), "The impact of Business Intelligence systems on stock return volatility", Information \& Management, Vol. 50, pp. 67-75.

Ruigrok, W., Wagner, H. (2003), "Internationalization and performance: An organizational learning perspective", Management International Review, pp. 63-83.

Sahay, B. S., Ranjan, J. (2008), "Real time business intelligence in supply chain analytics". Information Management \& Computer Security, Vol. 16 No. 1, pp. 28-48.

Setia, P., Patel, P. C. (2013). How information systems help create OM capabilities: Consequents and antecedents of operational absorptive capacity. Journal of Operations Management, Vol. 31, No. 6, pp. 409-431.

Shah, R., Ward, P. T. (2003), "Lean manufacturing: context, practice bundles, and performance", Journal of Operations Management, Vol. 21 No. 2, pp. 129-149.

Shefer, D., Frenkel, A. (2005), "R\&D, firm size and innovation: an empirical analysis", Technovation, Vol. 25, pp. 25-32. 
Silva, J. A. (2008), "International Trade and the Changing Demand for Skilled Workers in HighTech Manufacturing", Growth and Change, Vol. 39, pp. 225-251.

Sims, M. A., O’Regan, N. (2010), "What are High-Technology Firms and What Drives Their Performance?", New Technology-Based Firms in the New Millennium. Emerald Group Publishing Limited, pp. 173-188.

Sørensen, J. B., Stuart, T.E. (2000), "Aging, obsolescence, and organizational innovation", Administrative Science Quarterly, Vol. 45, pp. 81-112.

Swink, M., Harvey Hegarty, W. (1998), "Core manufacturing capabilities and their links to product differentiation", International Journal of Operations \& Production Management, Vol. 18, pp. 374-396.

Tallon, P. P., Pinsonneault, A. (2011), "Competing perspectives on the link between strategic information technology alignment and organizational agility: insights from a mediation model", MIS Quarterly, pp. 463-486.

Teece, D. J., Pisano, G., \& Shuen, A. (1997). Dynamic capabilities and strategic management. Strategic management journal, Vol. 18, No. 7, pp. 509-533.

Teo, T. S., Nishant, R., Koh, P. B. (2016), "Do shareholders favor business analytics announcements?", The Journal of Strategic Information Systems, Vol. 25, pp. 259-276.

Tippins, M. J., Sohi, R. S. (2003), "IT competency and firm performance: is organizational learning a missing link?", Strategic Management Journal, Vol. 24, pp. 745-761.

Trieu, V. H. (2017). Getting value from Business Intelligence systems: A review and research agenda. Decision Support Systems, Vol. 93, pp. 111-124.

Trkman, P. (2010), "The critical success factors of business process management", International Journal of Information Management, Vol. 30 No. 2, pp. 125-134.

Vandaie, R., Zaheer, A. (2014), "Alliance Partners and Firm Capability: Evidence from the Motion Picture Industry", Organization Science, Vol. 26, pp. 22-36.

Wang, H., Wang, S. (2008), "A knowledge management approach to data mining process for business intelligence", Industrial Management \& Data Systems, Vol. 108 No. 5, pp. 622634.

Watson, H. J., Abraham, D., Chen, D., Preston, D., Thomas, D. (2004), "Data warehousing ROI: Justifying and assessing a data warehouse", Business Intelligence Journal, Vol. 9, pp. 6-17. 
Winter, S. G. (2000)," The satisficing principle in capability learning", Strategic Management Journal, Vol. 21, pp. 981-996.

Wu, L. Y. (2006), "Resources, dynamic capabilities and performance in a dynamic environment: perceptions in Taiwanese IT enterprises", Information \& Management, Vol. 43, pp. 447-454.

Wu, S. D., Erkoc, M., Karabuk, S. (2005), "Managing capacity in the high-tech industry: A review of literature", The Engineering Economist, Vol. 50, pp. 125-158.

Yeoh, W., Koronios, A. (2010), "Critical success factors for business intelligence systems", Journal of Computer Information Systems, Vol. 50, pp. 23-32.

Yiu, D. L. M., Yeung, A. C. L., Cheng T. C. E. (2018), The Impact of Business Intelligence Systems on Profitability and Risks of Firms" Working Paper.

Yiu, D. L. M., Yeung A. C. L., Lam, H. K. S., Cheng, T. C. E. (2019), “Firms' Operational and Logistics Characteristics and Realisation of Business Analytics Benefits: Evidence from Stock Markets" Working Paper.

Zeng, L., Xu, L., Shi, Z., Wang, M., Wu, W. (2006), "Techniques, process, and enterprise solutions of business intelligence", in Systems, Man and Cybernetics, 2006. IEEE International Conference on IEEE, pp. 4722-4726.

Zhang, W. (2015). "R\&D investment and distress risk", Journal of Empirical Finance, Vol. 32, pp. 94-114.

Zhu, K., Kraemer, K. L., Xu, S., (2006), "The process of innovation assimilation by firms in different countries: a technology diffusion perspective on e-business", Management Science, Vol. 52 No. 10, pp. 1557-1576. 


\section{Tables}

Table 1. Propensity Scores Matching of Sample and Control Firms.

\begin{tabular}{|c|c|c|c|c|}
\hline \multicolumn{5}{|c|}{ Summary of balance for all data: } \\
\hline & $\begin{array}{r}\text { Mean difference of } \\
\text { the control firms } \\
\text { from the sample } \\
\text { firms } \\
\text { (Mean Diff) } \\
\text { ( } t \text {-statistics) }\end{array}$ & $\begin{array}{r}\text { Median of differences } \\
\text { in empirical quantile } \\
\text { functions } \\
\text { (eQQ Med) }\end{array}$ & $\begin{array}{r}\text { Mean of differences in } \\
\text { empirical quantile } \\
\text { functions } \\
\text { (eQQ Mean) }\end{array}$ & $\begin{array}{r}\text { Maximum value of } \\
\text { differences in } \\
\text { empirical quantile } \\
\text { functions } \\
\text { (eQQ Max) }\end{array}$ \\
\hline Distance & 0.030 & 0.029 & 0.030 & 0.076 \\
\hline Firm Size & $\begin{array}{r}1.444 \\
(10.358)^{* * *}\end{array}$ & 1.550 & 1.445 & 2.112 \\
\hline Organizational slack & $\begin{array}{r}-0.054 \\
(-1.857)^{* *}\end{array}$ & 0.078 & 0.159 & 22.908 \\
\hline Sales growth & $\begin{array}{r}-0.274 \\
(-0.269)\end{array}$ & 0.048 & 5.432 & 1506.715 \\
\hline Labor productivity & $\begin{array}{r}28.297 \\
(2.307)^{* *}\end{array}$ & 12.188 & 77.512 & 12351.169 \\
\hline Leverage & $\begin{array}{r}0.011 \\
(0.641)\end{array}$ & 0.035 & 0.068 & 6.768 \\
\hline Age & $\begin{array}{r}0.192 \\
(4.013)^{* * *} \\
\end{array}$ & 0.176 & 0.210 & 0.693 \\
\hline \multicolumn{5}{|c|}{ Summary of balance for matched data: } \\
\hline & $\begin{array}{r}\text { Mean Diff } \\
(t \text {-statistics })\end{array}$ & eQQ Med & eQQ Mean & eQQ Max \\
\hline Distance & 0.000 & 0.000 & 0.000 & 0.009 \\
\hline Firm Size & $\begin{array}{r}-0.103 \\
(-0.737)\end{array}$ & 0.281 & 0.316 & 1.335 \\
\hline Organizational slack & $\begin{array}{r}0.019 \\
(0.642)\end{array}$ & 0.024 & 0.036 & 0.669 \\
\hline Sales growth & $\begin{array}{r}0.066 \\
(0.065)\end{array}$ & 0.027 & 0.067 & 3.016 \\
\hline Labor productivity & $\begin{array}{r}-3.711 \\
(-0.303)\end{array}$ & 2.765 & 8.641 & 153.984 \\
\hline Leverage & $\begin{array}{r}-0.009 \\
(-0.479)\end{array}$ & 0.010 & 0.016 & 0.151 \\
\hline Age & $\begin{array}{r}0.038 \\
(0.800) \\
\end{array}$ & 0.057 & 0.065 & 0.406 \\
\hline \multicolumn{5}{|c|}{ Percent balance improvement: } \\
\hline $\begin{array}{l}\text { Distance } \\
\text { Firm Size } \\
\text { Organizational slack } \\
\text { Sales growth } \\
\text { Labor productivity } \\
\text { Leverage } \\
\text { Age }\end{array}$ & $\begin{array}{r}\text { Mean Diff } \\
99.899 \\
92.889^{\#} \\
65.422^{\#} \\
75.905 \\
86.885^{\#} \\
25.300 \\
80.075^{\#} \\
\end{array}$ & $\begin{array}{r}\text { eQQ Med } \\
99.978 \\
81.886 \\
69.587 \\
44.763 \\
77.314 \\
69.998 \\
67.657 \\
\end{array}$ & $\begin{array}{r}\text { eQQ Mean } \\
99.716 \\
78.156 \\
77.530 \\
98.760 \\
88.852 \\
77.060 \\
69.012 \\
\end{array}$ & $\begin{array}{r}\text { eQQ Max } \\
88.131 \\
36.803 \\
97.080 \\
99.800 \\
98.753 \\
97.767 \\
41.504 \\
\end{array}$ \\
\hline \multicolumn{5}{|c|}{ Sample sizes (Total number of firms): } \\
\hline $\begin{array}{l}\text { All } \\
\text { Matched } \\
\text { Unmatched } \\
\text { Discarded }\end{array}$ & $\begin{array}{r}\text { Control } \\
1098 \\
282 \\
816 \\
0 \\
\end{array}$ & $\begin{array}{r}\text { Treated } \\
282 \\
282 \\
0 \\
0 \\
\end{array}$ & & \\
\hline
\end{tabular}

\section{Notes:}

1. ${ }^{*} p<0.1, * * p<0.05$ and ${ }^{* * *} p<0.01$ (two-tailed).

2. \#Firm-specific factor is significantly different between the sample firms and control firms before PSM. 
Table 2. Descriptive Statistics of Pre-event Data for Sample and Control Firms (Year $t$-2).

\begin{tabular}{|c|c|c|c|c|c|c|}
\hline & $N$ & Mean & Median & Std. dev. & Min. & Max. \\
\hline \multicolumn{7}{|c|}{ Sample firms } \\
\hline Operational capability & 144 & 67.570 & 67.594 & 15.036 & 30.818 & 96.765 \\
\hline \multicolumn{7}{|c|}{ Control firms } \\
\hline Operational capability & 144 & 66.963 & 67.022 & 17.387 & 13.833 & 99.673 \\
\hline
\end{tabular}

${ }^{\mathrm{a}}$ In percent

Table 3. Abnormal Changes in Operational Capability.

\begin{tabular}{lcccc}
\hline Time period & $N$ & $\begin{array}{c}\text { Median } \\
\text { (Statistics) }\end{array}$ & $\begin{array}{c}\text { \% Positive } \\
\text { (Statistics) }\end{array}$ & Mean \\
(Statistics)
\end{tabular}

Notes:

1. ${ }^{*} p<0.1,{ }^{* *} p<0.05$ and ${ }^{* *} p<0.01$. The $p$-values shown are those for the one-tailed test of the null hypothesis that there is no abnormal operational capability, using the Wilcoxon signed-rank test, sign test, and $t$-test, respectively.

2. Wilcoxon signed-rank test Z-statistic for the median, binomial sign test Z-statistic for the percentage, and $t$-statistics for the mean.

3. \% Positive indicates the percentage of firms achieving positive abnormal changes in operational capability.

4. ${ }^{\mathrm{a}}$ In per cent. 


\section{Table 4. Correlations matrix}

\begin{tabular}{|c|c|c|c|c|c|c|c|c|c|}
\hline Variable & 1 & 2 & 3 & 4 & 5 & 6 & 7 & 8 & 9 \\
\hline 1. Cumulative abnormal operational capability & 1 & & & & & & & & \\
\hline 2. $R \& D$ intensity & 0.066 & 1 & & & & & & & \\
\hline 3. Firm Size & $0.259^{* * *}$ & -0.135 & 1 & & & & & & \\
\hline 4. Previous operational capability & $-0.287^{* * *}$ & 0.123 & 0.025 & 1 & & & & & \\
\hline 5. Year of BA adoption & 0.138 & -0.038 & $0.165^{*}$ & -0.043 & 1 & & & & \\
\hline 6. Age & $0.190^{* *}$ & $-0.271^{* * *}$ & $0.443^{* * *}$ & -0.067 & $0.207^{* *}$ & 1 & & & \\
\hline 7. Leverage & 0.111 & 0.044 & $0.246^{* *}$ & $-0.292^{* * *}$ & -0.046 & $0.269^{* * *}$ & 1 & & \\
\hline 8. Industry sales growth & $-0.205^{* *}$ & -0.006 & -0.093 & 0.061 & $-0.455^{* * *}$ & -0.136 & 0.075 & 1 & \\
\hline 9. Industry competitiveness & -0.046 & -0.024 & -0.048 & -0.044 & 0.156 & -0.083 & -0.099 & -0.128 & 1 \\
\hline Mean & 0.110 & 0.110 & 6.886 & 0.648 & 2007.259 & 3.485 & 0.165 & 0.201 & 0.782 \\
\hline Standard deviation & 0.753 & 0.154 & 1.836 & 0.167 & 2.102 & 0.895 & 0.176 & 0.113 & 0.206 \\
\hline
\end{tabular}


Table 5. Regression Analysis for Abnormal Operational Capability (Year $\boldsymbol{t}-2$ to Year $\boldsymbol{t}+\mathbf{1}$ ).

\begin{tabular}{|c|c|c|c|c|}
\hline Variables & Model 1 & Model 2 & Model 3 & Model 4 \\
\hline Intercept & $\begin{array}{l}-24.926 \\
(-0.328)\end{array}$ & $\begin{array}{l}-23.016 \\
(-0.305)\end{array}$ & $\begin{array}{l}-9.871 \\
(-0.132)\end{array}$ & $\begin{array}{l}-7.095 \\
(-0.096)\end{array}$ \\
\hline Previous operational capability & $\begin{array}{l}-1.213 * * * \\
(-2.779)\end{array}$ & $\begin{array}{l}-1.321 * * * \\
(-3.010)\end{array}$ & $\begin{array}{l}-1.327 * * * \\
(-3.083)\end{array}$ & $\begin{array}{l}-1.450 * * * \\
(-3.357)\end{array}$ \\
\hline Year of BA adoption & $\begin{array}{l}0.013 \\
(0.340)\end{array}$ & $\begin{array}{l}0.012 \\
(0.315)\end{array}$ & $\begin{array}{l}0.005 \\
(0.140)\end{array}$ & $\begin{array}{l}0.004 \\
(0.101)\end{array}$ \\
\hline Age & $\begin{array}{l}0.114 \\
(1.366)\end{array}$ & $\begin{array}{l}0.155^{*} \\
(1.789)\end{array}$ & $\begin{array}{l}0.039 \\
(0.440)\end{array}$ & $\begin{array}{l}0.081 \\
(0.893)\end{array}$ \\
\hline Leverage & $\begin{array}{l}0.013 \\
(0.030)\end{array}$ & $\begin{array}{l}-0.104 \\
(-0.239)\end{array}$ & $\begin{array}{l}-0.168 \\
(-0.391)\end{array}$ & $\begin{array}{l}-0.304 \\
(-0.703)\end{array}$ \\
\hline Industry sales growth & $\begin{array}{l}-1.090 \\
(-1.569)\end{array}$ & $\begin{array}{l}-1.020 \\
(-1.475)\end{array}$ & $\begin{array}{l}-1.056 \\
(-1.550)\end{array}$ & $\begin{array}{l}-0.977 \\
(-1.446)\end{array}$ \\
\hline Industry competitiveness & $\begin{array}{l}-0.267 \\
(-0.773)\end{array}$ & $\begin{array}{l}-0.246 \\
(-0.716)\end{array}$ & $\begin{array}{l}-0.257 \\
(-0.761)\end{array}$ & $\begin{array}{l}-0.234 \\
(-0.698)\end{array}$ \\
\hline $\mathrm{R} \& \mathrm{D}$ intensity & & $\begin{array}{l}0.742 * \\
(1.560)\end{array}$ & & $\begin{array}{l}0.810^{* *} \\
(1.741)\end{array}$ \\
\hline Firm Size & & & $\begin{array}{l}0.097 * * \\
(2.288)\end{array}$ & $\begin{array}{l}0.101 * * \\
(2.413)\end{array}$ \\
\hline $\mathrm{R}^{2}$ & $14.52 \%$ & $16.55 \%$ & $18.77 \%$ & $21.19 \%$ \\
\hline Adjusted $\mathrm{R}^{2}$ & $9.44 \%$ & $10.71 \%$ & $13.09 \%$ & $14.82 \%$ \\
\hline F-statistics & $2.859 * *$ & $2.833^{* * *}$ & $3.301 * * *$ & $3.326^{* * *}$ \\
\hline Incremental F-statistics & & 2.435 & $5.236 * *$ & $4.187 * *$ \\
\hline
\end{tabular}

Notes:

1. ${ }^{*} p<0.1,{ }^{* *} p<0.05$ and ${ }^{* *} p<0.01$ (two-tailed tests for control variables and one-tailed test for the moderating variables; $N=108$ ).

2. $t$-statistics in parentheses. 


\section{Appendices}

\section{Appendix 1}

Announcement Example:
\begin{tabular}{|l|l|}
\hline Announcement \\
\hline Company Name & Santarus Inc. (NASDAQ: SNTS) \\
\hline Announced on & 17 March 2008 (BA adoption i.e., year $t$ in 2009) \\
\hline $\begin{array}{l}\text { Industry } \\
\text { description (from } \\
\text { Factiva) }\end{array}$ & $\begin{array}{l}\text { Santarus Inc. is in the biotechnology and pharmaceuticals industry. The company } \\
\text { engages in acquiring, developing, and commercializing proprietary products which } \\
\text { address the needs of patients treated by physician specialists. }\end{array}$ \\
\hline $\begin{array}{l}\text { Text extracted } \\
\text { from Factiva }\end{array}$ & $\begin{array}{l}\text { Business intelligence leader SAS announced today that pharmaceutical } \\
\text { manufacturer Santarus, Inc. has selected SAS as a technology platform for data } \\
\text { integration, analysis and reporting for its commercial operations. With SAS, } \\
\text { Santarus will streamline its data integration efforts. Marketers will be able to drill } \\
\text { down into sales data to evaluate the merit of business opportunities quickly, such } \\
\text { as co-promotions and targeted marketing campaigns. }\end{array}$ \\
\hline
\end{tabular}




\section{Appendix 2}

The Distribution of Sample Firms Across Industries:

\begin{tabular}{|l|l|l|l|}
\hline 3-Digit SIC codes & Industries & Number & Percentage of sample \\
\hline 384 & Medical Instruments and Supplies & 22 & 15.28 \\
\hline 367 & Electronic Components and Accessories & 19 & 13.19 \\
\hline 382 & Measuring and Controlling Devices & 18 & 12.50 \\
\hline 357 & Computer and Office Equipment & 17 & 11.81 \\
\hline 283 & Drugs & 15 & 10.42 \\
\hline 366 & Communications Equipment & 12 & 8.33 \\
\hline 353 & Construction and Related Machinery & 9 & 6.25 \\
\hline 356 & General Industrial Machinery & 7 & 4.86 \\
\hline 358 & Refrigeration and Service Machinery & 4 & 2.78 \\
\hline 355 & Special Industry Machinery & 3 & 2.08 \\
\hline 362 & Electrical Industrial Apparatus & 3 & 2.08 \\
\hline Others & Other Industries & 15 & 10.42 \\
\hline Total & & 144 & 100 \\
\hline
\end{tabular}

\section{Appendix 3}

The Distribution of Sample Firms by Adoption Years of BI systems:

\begin{tabular}{|l|l|l|}
\hline Year & Number of BI Systems Adoption & Percentage \\
\hline 2005 & 26 & 18.06 \\
\hline 2006 & 28 & 19.44 \\
\hline 2007 & 26 & 18.06 \\
\hline 2008 & 13 & 9.03 \\
\hline 2009 & 12 & 8.33 \\
\hline 2010 & 8 & 5.56 \\
\hline 2011 & 7 & 4.86 \\
\hline 2012 & 8 & 5.56 \\
\hline 2013 & 8 & 5.56 \\
\hline 2014 & 8 & 5.56 \\
\hline
\end{tabular}




\section{Appendix 4}

\section{Variable Definition and Measurement:}

\begin{tabular}{|c|c|c|c|}
\hline Variable name & Measurement & Data source & Reference \\
\hline Operational capability & $\begin{array}{l}\text { Using the stochastic frontier estimation (SFE): } \\
\qquad \begin{array}{l}\ln (\text { Operating income })=\beta_{0}+\beta_{1} \ln (\text { Number of employee })+\beta_{2} \ln \text { (Capital expenditure) } \\
\qquad+\beta_{3} \ln (\text { Cost of goods sold })+\varepsilon-\gamma\end{array} \\
\text { where } \varepsilon \text { the purely stochastic random error term affecting operating income, and } \gamma \text { captures the } \\
\text { operational inefficiency of a firm in industry (2-digit SIC codes). } \\
\text { Operating capability }=(1-\hat{\gamma}) \times 100 \%\end{array}$ & Compustat & $\begin{array}{l}\text { Carmel and } \\
\text { Sawyer, 1998; } \\
\text { Dutta et al., } \\
2005 \text {; Li et al., } \\
2010\end{array}$ \\
\hline Previous operational capability & Previous operational capability $=$ The operational capability of a sample firm in the base year & Compustat & $\begin{array}{l}\text { Hendricks and } \\
\text { Singhal, } 2008\end{array}$ \\
\hline Abnormal operational capability & $\begin{array}{l}\text { Abnormal operational capability of a sample firm } \\
=\text { A sample firm's operational capability with BI adoption - A sample firm's expected } \\
\text { operational capability if BI adoption has not occurred } \\
\text { where A sample firm's expected operational capability if BI adoption has not occurred } \\
\text { is the sum of a sample firm's operational capability in the base year and the change in } \\
\text { operational capability of a control firm. }\end{array}$ & Compustat & $\begin{array}{l}\text { Barber and } \\
\text { Lyon, 1996; } \\
\text { Hendricks and } \\
\text { Singhal, } 2008\end{array}$ \\
\hline $\begin{array}{l}\text { Cumulative abnormal operational } \\
\text { capability }\end{array}$ & $\begin{array}{l}\text { Cumulative abnormal operational capability }=\text { The sum of abnormal operational capability of a } \\
\text { sample firm over the period from years } t-2 \text { to } t+1\end{array}$ & Compustat & $\begin{array}{l}\text { Barber and } \\
\text { Lyon, } 1996\end{array}$ \\
\hline R\&D intensity & $R \& D$ intensity $=R \& D$ expenditures $/$ Sales & Compustat & Lo et al., 2013 \\
\hline Firm size & Firm size $=\ln ($ Total assets $)$ & Compustat & Liu et al., 2014 \\
\hline Organizational slack & Organizational slack $=($ Current assets - Current liabilities $) /$ Total assets & Compustat & Luo et al., 2016 \\
\hline
\end{tabular}




\begin{tabular}{|c|c|c|c|}
\hline Sales growth & Sales growth $=$ The yearly change in sales of a firm & Compustat & Luo et al., 2013 \\
\hline Labor productivity & Labor productivity $=$ Operating income $/$ Number of employees & Compustat & Lo et al., 2013 \\
\hline Leverage & Leverage $=$ Total debts $/$ Total assets & Compustat & Luo et al., 2013 \\
\hline Age & Age $=\ln ($ Number of years from the date of incorporation $)$ & $\begin{array}{l}\text { Internet/ } \\
\text { Website }\end{array}$ & Zhang, 2015 \\
\hline Industry sales growth & Industry sales growth $=$ The yearly change in sales in an industry (based on 2-digit SIC codes) & Compustat & $\begin{array}{l}\text { Lo et al., } 2013 \\
\text { Hendricks and } \\
\text { Singhal, } 2008\end{array}$ \\
\hline Industry competitiveness & $\begin{array}{l}\text { Industry competitiveness }=\text { The sum of squared market shares of firms in an industry (based on } \\
\text { 2-digit SIC codes) }\end{array}$ & Compustat & Lo et al., 2013 \\
\hline
\end{tabular}


